Журнал«Герспективита інновації науки

(Серія «Гедагопіка», Серія«Гцихологія», Серія«Медицина»

№4(4) 2021

УДК 378.041:373.2(045)

https://doi.org/10.52058/2786-4952 -2021-4(4)-34-44

Shaparenko Khrystyna Andriivna Doctor of Pedagogical Sciences, Associate Professor, Professor of the Department of Theory and Methods of Preschool Education, Dean of the Faculty of Preschool, Special Education and History Municipal Establishment «Kharkiv Humanitarian Pedagogical Academy» of Kharkiv Regional Council, prov. Rustaveli, 7, Kharkiv, 61050, tel.: (050) 301-76-69, e-mail: kristsh@gmail.com, https://orcid.org/0000-0003-3616-2282

\title{
CONCEPTUAL FUNDAMENTALS OF SELF-IMPROVEMENT OF FUTURE PRESCHOOL TEACHERS
}

Abstract. Reforming the Ukrainian system of professional training of preschool teachers, namely its transition from focusing on established standards of professional activity to taking into account individual capabilities, abilities, spiritual needs of the individual in the system of vocational training involves finding effective ways of professional education of future preschool teachers. The article deals with the conceptual foundations of self-improvement of future preschool teachers in the process of professional training in higher education institutions. Attention is drawn to a number of contradictions with new, strengthened requirements for the level of forming personal potential of future preschool teachers and insufficient methodological tools to ensure the process of self-improvement in the system of professional training.

Modern approaches to pedagogical support of personality self-improvement are analyzed. The interrelations between the concepts of vocational education and upbringing and the process of self-improvement of future preschool teachers are determined. It is proved that only an educator who strives for constant self-improvement is able to create a spiritually rich developmental space in which a preschooler gains potential strength and needs for active self-affirmation through culturally significant forms of activity. The portrait of modern preschool teachers is characterized.

It is proved that training of future preschool teachers involves creating a holistic educational system, the main purpose of which is to teach students scientifically sound knowledge, skills, abilities of organizing the educational process with preschoolers to develop their personal potential.

Keywords: personality, self-improvement, personal potential, preschool teacher, pedagogical system, higher education institution, professional training, preschooler.

Шапаренко Христина Андріївна доктор педагогічних наук, доцент, декан факультету дошкільної і спеціальної освіти та історії Комунального закладу «Харківська гуманітарно-педагогічна академія» Харківської обласної ради, пров. Руставелі, 7, м. Харків, 61050, тел.: (050) 301-76-69, e-mail: kristsh@gmail.com, https://orcid.org/0000-0003-3616-2282 


\section{КОНЦЕПТУАЛЬНІ ОСНОВИ САМОВДОСКОНАЛЕННЯ МАЙБУТНІХ ПЕДАГОГІВ ДОШКІЛЬНОЇ ОСВІТИ}

Анотація. Реформування української системи професійної підготовки фахівців дошкільної освіти, а саме перехід ії від орієнтації на усталені стандарти професійної діяльності до врахування індивідуальних можливостей, здібностей, духовних потреб особистості в системі професійної підготовки передбачає знаходження ефективних шляхів професійного виховання майбутніх педагогів дошкільної освіти. У статті розглянуто концептуальні основи самовдосконалення майбутніх педагогів дошкільної освіти в процесі професійної підготовки у закладі вищої освіти. Звернено увагу на низку суперечностей новими, посиленими вимогами щодо рівня сформованості особистісного потенціалу майбутніх педагогів дошкільної освіти й недостатнім методичним інструментарієм забезпечення процесу самовдосконалення в системі професійної підготовки. Проаналізовано сучасні підходи до педагогічного забезпечення процесу самовдосконалення особистості. Визначено взаємозв'язки між поняттями професійної освіти і виховання та процесом самовдосконалення майбутнього педагога дошкільної освіти. Доведено, що лише вихователь, який прагне до постійного самовдосконалення, спроможний до створення духовно насиченого розвивального простору, у якому дитина дошкільного віку набирає потенційних сил та потреб в активному самоствердженні через культурно значущі форми діяльності. Охарактеризовано портрет сучасного педагога дошкільної освіти. Доведено, що підготовка майбутніх педагогів дошкільної освіти передбачає створення цілісної освітньої системи, основною метою якої $є$ засвоєння студентами науково обгрунтованих знань, умінь, навичок організації навчально-виховного процесу 3 дітьми дошкільного віку з метою розвитку їх особистісного потенціалу.

Ключові слова: особистість, самовдосконалення, особистісний потенціал, педагог дошкільної освіти, педагогічна система, заклад вищої освіти, професійна підготовка, дитина дошкільного віку.

Problem statement and its connection with important scientific or practical tasks. In the theory and practice of training professionals to work in a modern preschool institution, the issues of comprehensive development become especially relevant due to developing new content of training preschoolers focused on reflecting universal values. Thus, on the one hand, a unique role of preschool childhood is emphasized in the overall cycle of personality development, on the other hand, new educational requirements form the basis for subsequent formation of child's personality.

There is an urgent need to train future teachers - preschool educators - able to create conditions for comprehensive development of a child's personal potential 
and ready for continuous self-improvement.

Thus, in the third millennium, searching for ways to educate a human being of the future and find effective ways of professional training of future preschool teachers remains relevant for higher education. To solve the issue, it is necessary to create appropriate conditions for functioning, maintaining and expanding the network of preschool educational institutions; to update the content of preschool education in accordance with social needs, the needs of innovative development of society; to introduce modern means of development, training and education; to provide preparation and publication of educational and methodical literature; to improve the mechanism of monitoring the quality of preschool education, to provide training and further professional development of pedagogical staff of preschool educational institutions; to increase the level of work with parents, organization of consultative and educational work. Therefore, there is no doubt about a significant and fundamental role of education in forming and self-forming of man.

Analysis of the main references and publications in which the solution to this issue is initiated. The issue of professional education and training future preschool teachers is discussed in studies by such modern Ukrainian teachers as L. Artemova, H. Bielienka, A. Bohush, H. Burma, N. Havrish, N. Holota, O. Yemchyk, I. Dychkivska, L. Zdanevych, N. Kovalevska, N. Kolosova, A. Kurchatova, N. Lysenko, O. Listopad, S. Petrenko, L. Pisotska, T. Ponimanska, N. Saiko, T. Stepanova, T. Tanko, N. Tsybuliak, I. Shevchenko, M. Yaroslavtseva and others.

In the studies, the processes of self-improvement of preschool teachers are considered as a function of professional and pedagogical activities (K. Levitan, V. Slastionin, N. Kuzmina), a direction of pedagogical creativity (S. Sysoieva), constant professional development (T. Tikhonov), a non-stop development to become a teacher-ideal (E. Panasenko), improvement of professional skills (O. Chornousova), pedagogical culture (R. Skulsky), a main way of acquiring and maintaining professionalism (N. Huziy, O. Dubaseniuk, A. Markova, V. Khomych), an integral indicator of professional competence (L. Markelova), a criterion of teacher professionalism (A. Markova), a personal quality of a professional teacher (N. Kuzmina), which affects a teacher's professiogram (V. Slastionin).

Highlighting previously unsolved parts of the general problem to which this article is devoted. Analyzing the above references it is possible to identify a number of contradictions that justify the direction of this study between the focus of current training of future preschool teachers on established standards of professional activity and the need to take into account individual capabilities, abilities, spiritual needs; between new, strengthened requirements for the level of forming personal potential of future preschool teachers and insufficient methodological tools to ensure selfimprovement in the system of professional training.

Defining the article aims (task statement). The article is to cover and problemize issues of self-improvement of future preschool teachers in the process of professional training in higher education. 


\section{Presenting the main material of the study with justifying the obtained} scientific results. Scientists note that pedagogical contribution to creating a human being of the future involves advanced spiritual development, moral intelligence, ability to teacher's self-development and self-improvement. Only if the level of sociopedagogical competence of future preschool teachers is increased and personal selfimprovement is intensified, the task of achieving a new level of preschool education in preparing a a human being of the future can be solved.

The following definitions of the process of training future teachers are valuable for our research: mastering a certain system of professional knowledge, skills, abilities and personal qualities in institutions of higher and vocational education, capable of self-development, self-improvement and productive activity (S. Yashchuk) [3, p. 25]; development of a complex of personal and socially significant values and qualities of a future specialist, gradual assimilation of knowledge, skills, abilities and formation of pedagogical activity experience (L. Lebedyk) [7, p. 184].

M. Oliynyk defines training of future preschool specialists as a systematically organized educational process, the main purpose of which is to acquire psychological and pedagogical knowledge and provide continuous development in higher education, forming professional competencies on this basis that will determine the readiness of preschool teachers to professional activity [8, p. 28].

Analyzing the references gives a reason to note that some researchers (K. Levitan, R. Skulsky, N. Huziy, A. Markova, T. Tykhonova, Ya. Mitina) emphasize the importance of encouraging preschool workers to self-improvement to increase the quality of professional pedagogical activity, others (A. Derkach, O. Piekhota, N. Kuzmina) - for personal and professional growth of preschool teachers. Accordingly, there are two main approaches, conditionally called activity-supporting and personal-developmental.

Representatives of the activity approach (O. Bordeniuk, S. Yelkanov, B. Kindratyuk, K. Levitan, L. Mnatsakanyan, L. Ruvinsky, R. Skulsky and others) emphasize the functional aspect of professional and pedagogical self-improvement and describe it as an auxiliary direction of professional activities of preschool teachers, which should ensure high efficiency by self-improving preschool teachers' own qualifications, pedagogical skills and professional culture.

The idea of pedagogical support of individual self-improvement in one form or another is present in many systems of education. In the work "General advice to correct human actions", Ya. Comenisky argued that improving the whole world depends on a human being as a creator, on activity. This idea fully applies to the position of preschool teachers, who only in an effort to understand the nature of global changes taking place around, gets access to "correct human actions" and influence the future state of society. K. Ushynsky noted that "... in education, everything should be based on the personality of preschool teachers, because the educational power flows only from the living source of human personality. No statutes and programs, no artificial institution, no matter how cunningly it was invented, can replace the 
individual in education" [10, p. 321].

According to the German philosopher and theologian M. Kuzansky, "a human being can be a human God, and God can be a human angel, human beast, human lion, or bear, or anything else: within human potential is everything in its own way" [6, c. 259-260]. According to the quote, it can be concluded that at all times the development of society depends on the system of education and upbringing.

In most foreign systems and models of education, the task of educating child subjectivity is solved depending on the priorities of the tradition that exists in this society and in this system of education.

French educators cultivate value systems that, in their opinion, are characteristic of French society in the model of education, in the logic of the didactics of "New Schools", namely: personal, spiritual and ethical (charity, self-sacrifice, chastity, friendship); personal-economic and social (the right to work, to free choice of profession, to protect against unemployment, fair remuneration, a decent standard of living); career (right for professional growth); democratic (right for freedom of conscience, right for protection against discrimination on the grounds of race, nationality, sex, language, religion, social origin); political (right for persuasion); aesthetic (sense of beauty).

Psychologist P. White (the USA) considers "civil virtues" as an educational perspective. The program "Education of citizenship" includes training hope and confidence in oneself and the environment, courage, self-esteem, honesty and decency, as well as an ability to make friends.

British educators define the following groups of education values: values of freedom, equality and rationality; spiritual values as an integrative quality (attitude to the world); moral values (good and evil); environmental values; citizenship; values of health, art, healthy lifestyle.

The new educational paradigm of Western Europe and the United States actively supports the ideas of pedagogical hermeneutics, axiology, pedagogy of small groups, which are focused on finding ways to improve the effectiveness of continuous learning. The latter is also conceptually rethought as life-long education, starting with the "mother school", i.e. kindergarten. Practically all these directions are based on the ideas of teachers-reformers of the past (D. Dewey, M. Montessori, A. Diesterweg, N. Grundtvig, etc.).

In the educational space of such systems, a teacher works as a mentor and curator, introducing the child to the system of ethical and aesthetic ties between world and national cultures (Danish model of education according to Grundtvig), as an educatortutor (the USA), as an ombudsman) between family, society and school (Sweden), as a master sensei (Japan).

The model of "programmed learning" and education by W. Kilpatrick (the USA) is considered interesting, within which students are given the right to freely choose classes, adjust the content of programs. The teacher assists pupils as an educator and tutor-mentor. 
The most popular education model according to the system of John Howard (the USA) - PACE - model: a model of programmed autonomous advancement of pupils on individual trajectories of development (with step-by-step advancement and selfcontrol in integration courses). According to the education model of hang glider (Great Britain, the USA), it is also focused on the idea of free development of the child. Pupils have the right to choose classes according to a flexible and variable schedule, learn to work and live in microgroups (learning option within the model of the project-based learning "cooperative learning").

In France, the model "Pedagogical Workshops" is vigorously promoted (workshops belong to the British tradition, while in French "New School" "les ecoles nouvelles", they are known as les Ateliers).

Teach-in systems are actively being developed: literally meaning inside learning, which provides for holding debates, seminars, discussion platforms, educational meetings to discuss current topics.

It is worth emphasizing that the teacher's self-improvement is not reduced to a simple combination of professional self-education, but is a qualitatively different and more complex process. T. Shestakova emphasizes that "if a teacher self-education means independent mastering of necessary knowledge, skills and forming professionally significant qualities, then personal self-improvement provides deepening and expanding already acquired knowledge by educators, improving formed skills, qualities and abilities. monological thinking, consciousness and self-awareness, integrative qualities, such characteristics of preschool teachers as competence, emotional and behavioral flexibility, etc." [9].

Representatives of the personal-development approach (V. Andreev, N. Kuzmina, L. Markelova, L. Mitina, O. Piekhota, V. Tertychna, P. Kharchenko, etc.) consider self-improvement to be a leading direction in a teacher's professional activities, which ensures personal growth and promotes effective self-realization in profession [9]. A teacher's self-improvement is considered mainly in the context of such phenomena as pedagogical creativity, professionalism, professional competence of a teacher, professional self-development.

Ensuring a holistic educational process in higher education should be aimed at enriching personal experience of cognition with subjective experience that preschool teachers already have, then the process of acquiring knowledge ceases to be an aim in itself, and is understood as a means of self-formation, self-construction, selfimprovement; formation of the foundations of a philosophical system of thinking. All the means necessary are available for each individual "they never belonged to the masses and will not belong to them. They have never been and will never be a matter of civilization, they are the property of culture "[1, p. 26].

For the most part, pedagogical higher education orients students to acquire knowledge through teachers, which determines the mostly uninitiated, passive state of personality. But in the conditions of constant updating the scientific information, the main thing for the expert becomes independent search and selection of the information 
which is necessary for further improvement. Therefore, the development of future preschool specialists should be focused on developing the inner world of the individual as a free spiritual person in need of personal growth.

From an individual, who is perceived as the object of education, there must be a transition to individuality - the subject of education, free spiritual personality, capable of self-improvement as the highest of the conscious forms of self-development. The main task of training future preschool specialists is recognizing selfdevelopment and self-improvement of the individual in all its manifestations.

From these positions it is possible to determine the relationship between the concepts of vocational education and the process of self-improvement of future preschool teachers:

the process of professional education in a higher education institution is determined by the needs of society and requirements for personal development (O. Yemchyk) [4, p. 56];

- the process of professional education involves forming the cognitive sphere of students and developing their intellectual abilities; getting to know the content, methods, techniques, personality-oriented technologies of educational interaction; forming students' stable need for constant selfimprovement, promoting comprehensive development of the student's personality, forming subjective self-esteem; developing students' abilities to make independent judgments and conclusions; developing creativity and personal reflection;

one of the components of professional education of future preschool teachers in higher education institutions is representing relevant scientific information on the content, principles, methods, techniques, technologies of personal self-improvement through independent educational activities;

the main tasks of supporting desire for personal self-improvement of future preschool teachers are as follows: increasing students' interest in pedagogical activities, forming their professional values, ideals and beliefs, developing pedagogical abilities; developing and supporting cognitive interests of students, creating an atmosphere of joint creativity, collective responsibility, interest in the success of peers; creating conditions for students to acquire a system of knowledge aimed at forming individual creative experience, and forming primary skills of professional pedagogical activity through involvement in pedagogical practice; setting before students pedagogical goals, the achievement of which requires maximum expression of creative abilities; involving future teachers in research and experimental work, implementing independent research and creative tasks, promoting various tools and systems for processing scientific and technical information; organizing and holding competitions, contests; introducing tasks for reflection, training of communicative abilities, implementing micro-research, etc ;

- a significant role in the process of personal self-improvement of future preschool teachers is active participation in the study of educational practice, including independent search for material on education, study of various \&qientific and 
educational sources, careful analysis of professional activity through self-observation, research, search ways and methods of solving selected problems, etc .;

- $\quad$ methods and ways to stimulate the process of personal self-improvement of students are as follows: forming cognitive and professional-value motives of educational activities; clear definition of the activity goal and final results of work, estimation methods; creating a developmental environment that encourages discussions, diversifying views and judgments; providing creative search activities; motivating to generate new ideas; practical orientation of educational activity; simulating life situations, using role-playing games, training sessions, joint problem solving, etc .;

- $\quad$ among the results of professional education of future preschool teachers the following abilities are highlighted: an ability to create programs of personal selfdevelopment and self-improvement; an ability to predict possible options for the development of events in the proposed situations; skills of developing alternative models of education; creating and protecting creative projects of personal selfimprovement.

This poses special challenges for higher education: to apply and implement pedagogy of partnership, to seek ways to individualize training of graduates, to introduce personal self-improvement projects to develop mechanisms of selfregulation, self-knowledge, self-analysis, self-knowledge in training future preschool teachers.

Another aspect is training future educators to ensure development of personal potential of preschool children. We consider a personal potential of a preschool child as a mechanism of infant activity, which occurs in all specifically children's activities in childhood and is manifested in methods (ways) of cognition and discovery of the world and means of reflecting this creative process of interaction with the world in images and mental models, creating own model of the world. The need for selfaffirmation, in conditions when a child has not yet discovered and confirmed his abilities in real activities, is the main and bright sign of potential creative forces that stimulate a desire for development.

The authors believe that only a preschool teacher who strives for constant selfimprovement is able to create a spiritually rich developmental space in which a preschool child gains potential strength and needs for active self-affirmation through culturally significant forms of activity.

In transiting from a sociocentric worldview paradigm to an individual-centric one, it is important to form a system of values of future specialists, where universal and national values would be dominant, and principles of humanism, patriotism, justice would be basic. Forming human-centered orientation of the worldview of specialists is discussed. Information civilization with its individual-centric worldview paradigm encourages forming not so much socially typical, but especially individual, i.e. the individuality of each person [5, p. 152].

The portrait of a modern preschool teacher should look like this: self-confident, 
striving for personal self-improvement; enterprising, responsible, successful, competitive, erudite, knowledgeable and creative, has the means to succeed in life; one that has innovative methods of developing personal potential of a preschooler, an ability to organize a holistic educational process in a preschool institution; developing a cultural potential of the country; recognizing efficiency, persistence and rationalism; valuing life, health, family, independence, realizing a need for strong will, sociability, ability to build relationships.

At the same time, it should be borne in mind that the following principle applies in the educational process: the level of self-knowledge, self-education and selfimprovement of students is directly dependent on the focus of higher education teachers on their own self-knowledge, self-education and self-improvement. The activity of both teachers and students shows the following pattern: self-education affects self-knowledge, self-education and self-knowledge affects self-education, and self-knowledge in turn has the opposite effect on self-education, self-education - on self-knowledge and self-education, providing self-improvement. The teacher's presentation of the process of personal self-improvement in teaching motivates students to work together, creating a positive attitude to both experience and cognitive activity in general, which ensures success of personal self-improvement of students. This is how internal, hidden reserves of pedagogical interaction are revealed. The revealed regularity determines the basis of the system of personal self-improvement of both students and teachers at higher educational institutions.

Organizing interaction of subjects of educational environment in the space of noosphere education provided by teachers is viewed as involvement of future preschool teachers not only in universal spiritual culture and values, as landmarks of self-realization and self-actualization, but also in pedagogical society changing in the context of self-improvement.

Conclusions and further prospects. Summarizing, it should be noted that training of future preschool teachers in the context of our study involves creating a holistic educational system, the main purpose of which is to teach students scientifically sound knowledge, skills of organizing the educational process for preschoolers to develop their personal potential; ensuring a continuous process of personal self-improvement, education of socially important personality traits related to the system that provides mastery of tools and models of alternative learning, personal self-improvement techniques, methods of working with children with special educational needs, able to overcome contradictions in spiritual development, ready to create a psychologically safe and comfortable inclusive environment.

\section{References:}

1. Aseev A. G. (1978) O dialektike determinacii psihicheskogo razvitija. Princip razvitija v psihologii [On the dialectic of the determination of mental development. The principle of development in psychology] / otv. red. L. I. Anciferova. Moskva. 235 s. [in Russian]. 
2. Hoy W. K., Woolfolk A. E. Socialization of student teachers. American Educational Research Journal. 1990. № 27(2). P. 279-300. URL : doi:10.3102/00028312027002279 (date of the application : 24.12.2018).

3. Iashchuk S. M. (2015) Profesiina pidhotovka mahistriv tekhnolohichnoi osvity: teoriia ta metodyka : monohrafiia [Professional training of masters of technological education: theory and methods: monograph]. Uman: Zhovtyi O. O. 367 s. [in Ukrainian].

4. Iemchyk O. H. (2018) Rozvytok tvorchoho potentsialu mahistriv doshkilnoi osvity u protsesi profesiinoi pidhotovky [Development of creative potential of masters of preschool education in the process of professional training] : dys.... kand. ped. nauk : 13.00.04 / Rivnenskyi derzhavnyi humanitarnyi universytet. Lutsk. $318 \mathrm{~s}$. [in Ukrainian].

5. Ieratrokhina O. M. (2013) Camovdoskonalennia osobystosti u naukovii refleksii i realizatsii biohrafichnykh proektiv: monohrafiia [Self-improvement of personality in scientific reflection and realization of biographical projects: monograph] . Kharkiv : Vyd-vo Ivanchenka I. S. 215 s. [in Ukrainian].

6. Krasnoshchok I. P. (2002) Osobystisna samorealizatsiia maibutnoho vchytelia v navchalnovykhovnomu seredovyshchi pedahohichnoho universytetu [Personal self-realization of the future teacher in the educational environment of the pedagogical university]: dys. kand. ped. nauk : 13.00.07. Kirovohrad. 214 s. [in Ukrainian].

7. Lebedyk L. (2009) Pryntsypy pedahohichnoi pidhotovky maibutnikh mahistriv ekonomiky yak vykladachiv vyshchoi shkoly [Principles of pedagogical training of future masters of economics as teachers of higher school]. Visnyk Lvivskoho universytetu. 2009. Vyp. 25. Ch. 3. C. 183-190. [in Ukrainian].

8. Oliinyk M. V. (2016) Teoretyko-metodychni zasady pidhotovky maibutnikh fakhivtsiv doshkilnoi osvity $\mathrm{v}$ krainakh Skhidnoi Yevropy [Theoretical and methodological principles of training future specialists in preschool education in Eastern Europe] : dys. ... dokt-ra ped. nauk : 11.00.01. Ternopil. 475 s. [in Ukrainian].

9. Shestakova T. V. (2006) Formuvannia hotovnosti maibutnikh pedahohiv do profesiinoho samovdoskonalennia [Formation of readiness of future teachers for professional self-improvement] : dys... kand. ped. nauk: 13.00.04 / Natsionalnyi pedahohichnyi un-t im. M.P.Drahomanova. K. 250 s. [in Ukrainian].

10.Ushinskij K. D. Sobranie sochinenij : v 11-ti T. 8 : Chelovek kak predmet vospitanija. Opyt pedagogicheskoj antropologii (1950) [Man as a subject of education. Experience in pedagogical anthropology] / sost. V. Ja. Struminskij. Moskva ; Leningrad : Akad. ped. nauk RSFSR. 776 s. [in Russian].

\section{Лimepamypa:}

1. Асеев А. Г. О диалектике детерминации психического развития. Принцип развития в психологии / отв. ред. Л. И. Анциферова. Москва, 1978.

2. Ємчик О. Г. Розвиток творчого потенціалу магістрів дошкільної освіти у процесі професійної підготовки : дис.... канд. пед. наук : 13.00 .04 / Рівненський державний гуманітарний університет. Луцьк, 2018. 318 с.

3. Сратрохіна О. М. Самовдосконалення особистості у науковій рефлексії і реалізації біографічних проектів: монографія. Харків : Вид-во Іванченка I. С. , 2013. 215 с.

4. Краснощок I. П. Особистісна самореалізація майбутнього вчителя в навчальновиховному середовищі педагогічного університету : дис. канд. пед. наук : 13.00.07. Кіровоград, 2002. $214 \mathrm{c}$.

5. Лебедик Л. Принципи педагогічної підготовки майбутніх магістрів економіки як викладачів вищої школи. Вісник Львівського університету. 2009. Вип. 25. Ч. 3. С. 183-190.

6. Олійник М. В. Теоретико-методичні засади підготовки майбутніх фахівців дошкільної освіти в країнах Східної Європи : дис. ... докт-ра пед. наук : 11.00.01. Тернопіль, 2016. 475 с.

7. Ушинский К. Д. Собрание сочинений : в 11-ти Т. 8 : Человек как предмет воспитания. Опыт педагогической антропологии. / сост. В. Я. Струминский. Москва ; Ленинград : Акад. пед. наук РСФСР, 1950. 776 с. 
8. Шестакова Т. В. Формування готовності майбутніх педагогів до професійного самовдосконалення : дис... канд. пед. наук: 13.00.04 / Національний педагогічний ун-т ім. М.П.Драгоманова. К., 2006. 250 с.

9. Ящук С. М. Професійна підготовка магістрів технологічної освіти: теорія та методика: монографія. Умань: Жовтий О. О., 2015. 367 с.

10. Hoy W. K., Woolfolk A. E. Socialization of student teachers. American Educational Research Journal. 1990. № 27(2). P. 279-300. URL : doi:10.3102/00028312027002279 (date of the application : 24.12.2018). 